\title{
THE ASCENT OF THE EUROPEAN COMMISSION AS AN ACTOR IN THE MONETARY INTEGRATION PROCESS IN THE 1960s
}

Ivo Maes*

* National Bank of Belgium, University of Leuven and ICHEC. Part of the research for this paper was undertaken when the author was a Visiting Fellow, at the Robert Schuman Centre, European University Institute. Earlier versions were presented at seminars at the Robert Schuman Centre, the Universities of Erfurt, Roma Tre, Porto and Limerick and the 2004 HES, AISPE and UACES meetings. I am indebted to many persons for assistance and useful discussions and suggestions, especially J.-P. Abraham, D. Andrews, J. Backhaus, F. Brandão, S. Bertholomé, H. Famerée, J. Flory, E. Jacobs, A. Palumbo, P. Santella, J. Smets, L. Quaglia and H. Wallace.

$\begin{array}{ll}\text { Address: } & \text { Research Department } \\ & \text { National Bank of Belgium } \\ & \text { Boulevard de Berlaimont } \\ & 1000 \text { Brussels } \\ & \text { Belgium } \\ & \text { tel: 32-2-2212796 } \\ & \text { fax: 32-2-2213162 } \\ & \text { e-mail ivo.maes@nbb.be }\end{array}$




\title{
THE ASCENT OF THE EUROPEAN COMMISSION AS AN ACTOR IN THE MONETARY INTEGRATION PROCESS IN THE 1960S
}

\begin{abstract}
This paper discusses macroeconomic and monetary policy-making at the European Commission in the 1960s. The Commission, in its analysis, focussed strongly on economic imbalances in the Community, as they could threaten the common market project. In order to strengthen the system of economic governance of the Community, the Commission advocated an improved monetary cooperation, in line with the internal logic of the integration process. This contrasted with the view of the central bankers, who took the international monetary system as the framework for their analysis. The paper shows the ascent of the Commission as an actor in the monetary area, notwithstanding the relatively limited provisions of the EEC Treaty.
\end{abstract}

JEL codes: A11, B20, E60, F02, N14, P16.

Keywords: Economic governance, EMU, Monetary cooperation, European Commission, European Reserve Fund, 1962 Action Programme, Barre Memorandum. 


\section{INTRODUCTION}

As observed by Tinbergen (1954), economic integration concerns the regulation of international relations. As such, it is in essence a question of the organisation of economic policy, a highly political issue. It is noteworthy that, in the mid 1950s, the six "Schuman" countries that created the European Coal and Steel Community, followed two rather different paths to economic integration. The six countries opted for regional integration of the goods markets, with the creation of the European Economic Community (EEC). However, monetary integration was approached from a more world-wide perspective, with the restoration of complete external convertibility in the framework of the Bretton Woods system (Abraham \& Lemineur-Toumson, 1981). These approaches would largely determine how the Commission and the central bank governors of the Community viewed monetary issues. For the Commission, monetary integration was linked with the integration of the goods markets, where agriculture would occupy a special place. This contrasted with the perspective of the central bankers of the Community, for whom currency issues were, in the first instance, an issue related to the international monetary system.

In this paper the focus is on macroeconomic and monetary policy-making at the European Commission, covering the period from the Rome Treaties to the Hague Summit. The EEC Treaty was, de facto, of a constitutional order and would transform economic and legal rules in the countries of the Community. Moreover, as is well known, the EEC Treaty was a framework treaty. One of the main objectives of this paper is to investigate how the Commission, on the basis of the treaties, sought to develop its role in the macroeconomic and monetary area. Therefore, the focus of the paper is on three crucial macroeconomic policy documents of the period under consideration: the proposal for a European Reserve Fund in 1958, the Commission's Action Programme for the Second Stage of the EEC of 1962 and the Barre Memorandum of October 1969. The paper thus analyses the gradual emergence of the Commission as an actor in the monetary area. To set the scene, the paper starts with an overview of the economic philosophy of the Rome Treaties, senior macroeconomic policymakers at the Commission and economic developments in the 1960s. The paper is based on an analysis of public documents, new archival research and a large scale programme of interviews with former policy-makers (cf. annex 1). 


\section{THE ROME TREATIES: AN ECONOMIC THOUGHT PERSPECTIVE}

After the failure of the plan for a European Defence Community (EDC), the Benelux countries revived the integration process with the common market project. As the rejection of the EDC plan was a setback to political integration, the economic element was pushed to the forefront (Issing, 2000). The ensuing Rome Treaties reflected the priorities and sensitivities of the Member States. In the post-war period, there were significant differences in ideas and economic policy-making, especially between France and Germany. In Germany, the economic order was based on the concept of the social market economy (Tietmeyer, 1999). In France, the state played a greater role in economic life and pursued more activist economic policies, with "the Plan" taking an important place. These differences in economic ideas were to a large extent based on more fundamental underlying differences in "metabeliefs" (Maes, 2004). The "republican tradition" in France stressed the sovereign nation as the source of legitimacy and, consequently, the political direction of economic policy. The post-war German federal system stressed decentralisation and a division of power. The social market economy fitted in with this conception.

During the EEC negotiations, the German government was deeply concerned about the new European economic system that would be created. One of the main German aims was that the European common market should have the same economic order as the Federal Republic, based on the principles of a market economy and a liberal trade policy. The Germans feared that interactions with more etatist and planned economies, through the common market, could imperil the consistency of their own economic system (von der Groeben, 1979, p. 496).

The French favoured a greater role for the state in economic life. In a policy memorandum, the French government proposed the idea of planning on a European scale: "A policy of expansion ... implies investment which, in the basic industries, in the chemicals industry, in many of the processing industries, rests on a precise conception of the targets to be assigned to production over a period of several years. Convergence of the different national economic policies can therefore be ensured only by reconciling and harmonising national production objectives" (as quoted in Marjolin, 1986, p. 287). Moreover, the French government was very concerned that France was not in a position to engage in 
competition on equal terms. It was therefore in favour of harmonisation of legislation which affected the competitive position, especially social legislation.

The EEC Treaty was, de facto, of a constitutional order and would transform economic and legal rules in the countries of the Community (Padoa-Schioppa, 1998, p. 9). Looking at the Rome Treaties from an economic thought perspective, the European Atomic Energy Community (EAEC) bears a French (planning) imprint, with its sectoral approach, while the European Economic Community, with the abolition of barriers to the free movement of goods, services, labour and capital in the common market and strong emphasis on competition policy, shows a stronger German influence ${ }^{1}$. France obtained the extension of the common market to agriculture and the association of the overseas territories. The social chapter was rather limited.

Compared with commercial policy or competition policy, for example, the responsibilities of the Commission were rather limited with respect to macroeconomic and, especially, monetary issues. Triffin (1958, p. 1) described the limited monetary dimension of the EEC Treaty as "a Hamlet in which the role of the Prince of Denmark is almost totally ignored". The Treaty left macroeconomic policymaking mainly at the level of the Member States. The responsibilities of the Commission concerned the orientation and co-ordination of the national macroeconomic policies.

The part of the Treaty on "Economic Policy" comprised three chapters: "Conjunctural Policy", "Balance of Payments" and "Commercial Policy". The integration project goes farthest in the area of commercial policy, where, after the transitional period, "a uniform commercial policy" is foreseen (Article 111) ${ }^{2}$. The chapter on "Conjunctural Policy" is rather short (only one article). It stipulated that macroeconomic policy, while being a matter of common concern, remained a responsibility of the Member States. Article 103.1 said that "Member States shall regard their conjunctural policies as a matter of common concern. They shall consult each other and the Commission on the measures to be taken in the light of the prevailing circumstances". The procedures to be followed were indicated in Article 103.2, which stated that: "the Council may, acting unanimously on a proposal from the Commission, decide upon

1 Free movement of capital was more limited, in response to French pressure. Moreover, France also obtained the "safeguard clauses" (cf.infra).

2 As the references are to the original EEC Treaty, the original numbering of the articles is followed. 
the measures appropriate to the situation". In 1960, after a German initiative, the "Short-term Economic Policy Committee" was created on the basis of Article 103.

The most extensive discussion of macroeconomic and monetary issues can be found in the chapter "Balance of Payments". It further illustrates that macroeconomic and monetary issues were tackled from a "common market" perspective, as balance of payments disequilibria would threaten the creation and functioning of the common market. Also in this area, the German and French negotiators followed different approaches, partly due to differences in the economic situation in their countries.

Article 104 states that each Member State should pursue an economic policy "to ensure the equilibrium of its overall balance of payments and to maintain confidence in its currency, while taking care to ensure a high level of employment and a stable level of prices". Otmar Emminger (Deutsche Bundesbank) considered this a "fundamental" article as it implied the commitment of every Member State to adopt economic policies which would ensure balance of payments equilibrium (Emminger, 1958, p. 93).

Article 105 continues that, in order to attain the objectives of Article 104, "Member States shall coordinate their economic policies". It states that the Member States "shall for this purpose institute a collaboration between the competent services of their departments and between their central banks". Already in January 1958, the Governors of the central banks decided to organise this cooperation, informally in Basle, and informed the Commission of this. It was a pre-emptive action by the Governors, who where afraid of a potential Commission initiative which might institute more tight rules (Pluym and Boehme, 2004, p. 117).

Article 108 discusses the situation where a Member State has serious balance of payments difficulties which could threaten the functioning of the common market. It stipulates that the Commission should investigate the situation and that the Commission can recommend measures for the Member State to take. Moreover, the article provides for the possibility of granting "mutual assistance". Article 109 contains the famous safeguard clauses, which France insisted on, whereby, in the case of a sudden balance of payments crisis, a Member State can take the "necessary protective measures". 
The Treaty, in Article 105.2, also provided for the establishment of the Monetary Committee. It was based on a French Memorandum (Archives NBB, B 436/4). The Memorandum noted that in the monetary area, which remained a matter of national sovereignty, efficient cooperation was necessary for the functioning of the common market. The proposed missions of the Monetary Committee were to provide reciprocal information for the various authorities and to formulate opinions on "all aspects of monetary policy concerning the functioning of the common market". The Memorandum explicitly mentioned the mutual assistance procedure.

During the negotiations, the exchange rate issue was also a topic of serious discussions. According to Van Tichelen (1981, p. 340), one of the Belgian negotiators, one of the main points of disagreement was whether it should be a national or a Community competence. The Belgian delegation, inspired by a Commonwealth formula, proposed that "Each Member State shall treat its policy with regard to rates of exchange as a matter of common concern" (Article 107.1). It was an ambiguous formula, but it succeeded in placing the exchange rate in the area of competence of the Community.

\section{SENIOR MACROECONOMIC POLICY-MAKERS AT THE COMMISSION}

It is the College of the Commission which is ultimately responsible for policy-making at the European Commission $^{3}$. The first president was Walter Hallstein (D). He was succeeded, in 1967, by Jean Rey (B). The initial organisation chart of the Commission was remarkably simple and reflected very well the structure of the EEC Treaty. The Commission initially comprised nine directorates-general (departments), giving a good overview of the activities of the EEC. These were External Relations, Economic and Financial Affairs (the macroeconomic research department), Internal Market, Competition, Social Affairs, Agriculture, Transport, Overseas Countries and Territories, and Administration. One can observe a Franco-German balance in the allocation of responsibilities for

3 In the EEC terminology, the term "Commission" is used both for the College of the Commission, the body of commissioners, and for the Commission departments, the administration. 
economic policy. The Germans had the competition policy portfolio, with Hans von der Groeben. The French had a key role in macroeconomic policy, as Robert Marjolin became responsible for Economic and Financial Affairs. He was succeeded, in 1967, by Raymond Barre (cf. Table 1). Marjolin and Barre were both very prominent French economists. Their impact was even more important, as the Commission administration was quite small at that time.

Table 1 - Senior macroeconomic policy-makers at the European Commission

\begin{tabular}{|l|c|c|}
\hline & Hallstein Commission & Rey Commission \\
\hline $\begin{array}{l}\text { Member responsible for DG II (Economic } \\
\text { and Financial Affairs) }\end{array}$ & R. Marjolin (F) & R. Barre (F) \\
$\begin{array}{l}\text { Chef de cabinet } \\
\text { Director-General of DG II }\end{array}$ & J. Flory (F) & J.-C. Paye (F) \\
$\begin{array}{l}\text { Directors: } \\
\text { - National economies and business cycle }\end{array}$ & F. Bobba (I) & Uosca (I) \\
- Monetary matters & P. Millet (F) & B. Molitor (D) \\
- Structure and development & L. Gleske (D) & F. Boyer de la Giroday (F) \\
- Budgetary matters & M. Albert (F) \\
Secretary of the Monetary Committee & L. Duquesne de la Vinelle (B) & G. Wissels (N) \\
& A. Prate (F) & R. de Kergorlay (F) \\
\hline
\end{tabular}

1 Created in 1967.

Marjolin is considered as one of the few prominent "Keynesian" economists in France, developing in his doctoral dissertation a long-run dynamic theory (Arena and Schmidt, 1999, p. 93). He later became the deputy of Monnet at the French Planning Office and the first Secretary-General of the Organisation for European Economic Cooperation. During his time at the Commission he was also very much interested in the issue of a medium-term economic policy ${ }^{4}$. Barre was quite professorial, with a wide knowledge of economic theory. He was very much a man of "economic discipline", convinced of the importance of stable prices and exchange rates ${ }^{5}$. He also had policy experience as the chef de cabinet of Jeanneney, De Gaulle's Minister of Industry in 1958, a post which entailed supervising the

4 According to an interviewee, Monnet and Marjolin did not really grasp the idea of the market. For them, economics was a question of "steering from above".

5 Barre (2000, p. 19) mentions that it was in Brussels that he got to know the differences between the approaches of the French administration ("a keen sense of interventionism, supported by a certain lack of understanding of the market" and "formally or informally protectionist") and the German approach. 
abolition of tariffs and quotas, as required by the Rome Treaty.

At the level of the administration, the Directors-General of DGII have traditionally been Italians. The first one, Franco Bobba, was a former diplomat. He was succeeded by Ugo Mosca, also a diplomat. Both Bobba and Mosca had a reputation for being good organisers and negotiators, but less for providing analytical stimulation to the DG (where Marjolin and Barre played a key role).

Initially, DGII consisted of three directorates, reflecting the main preoccupations of macroeconomic policy-makers at the Commission. A first directorate, "National economies and business cycle", was responsible for monitoring the economic situation and the business cycle in the Community. The second directorate was "Monetary matters". Important tasks of this directorate were the monitoring of the monetary situation (inside the Community but also the international monetary system) and the preparation of directives for the liberalisation of capital movements ${ }^{6}$. The third directorate was "Structure and development". In many ways, e.g. medium- term forecasts, sectoral analyses, and structural programmes, it bore a close resemblance to the (French) Planning Office. In 1967 Barre created a directorate for "Budgetary matters". Another important person was the Secretary of the Monetary Committee ${ }^{7}$. Also very influential was Robert Triffin, an advisor, but very close to Marjolin ${ }^{8}$.

6 The focus of this paper is on macroeconomic and monetary issues. For a discussion of the issue of the liberalisation of capital movements, see Bakker, 1996.

7 At the start of the Communities, the economic situation in France and the threat of French use of the safeguard clauses were major causes of concern. One can observe that many of the crucial positions for the assessment of the (French) situation were occupied by French persons. The economic situation would be discussed in the Monetary Committee, of which Prate was the Secretary. The report would be submitted by the Directorate of National Economies and Business Cycles (Millet) of DG II, for which Marjolin was responsible. Moreover, the Director-General for the Internal Market was Ortoli.

8 An indication of Marjolin's appreciation of Triffin is given by his salary, which was at the level of a Director-General (Minutes of the Meeting of the Commission of 19-20/11/1958, COM(58) PV 38, secret part, Archives European Commission). 


\section{THE EUROPEAN COMMUNITY IN THE 1960S}

As discussed earlier, in the EEC Treaty macroeconomic and monetary issues were approached very much from a balance of payments perspective, as balance of payments problems could threaten the common market project. It is thus important to analyse the economic shocks which affected the European Community, and, especially, the balance of payments.

The balance of payments can be affected by "asymmetric shocks" hitting a Community country. The two most important asymmetric shocks occurred in France, in the late 1950s and in 1968. France in the late 1950s was living through the final years of the Fourth Republic. The political uncertainty and the war in Algeria contributed to a volatile economic situation. In these circumstances, monetary and fiscal policy were lax. In 1958 inflation exceeded 10\% and the balance of payments showed a deficit (cf. Figure 1). This was a serious problem for pro-Europeans in France: how could France participate in the common market project with this kind of macroeconomic imbalances? It was also a major concern for the Commission, as senior French officials were thinking of using the safeguard clauses (Jeanneney, 2004). In December 1958, De Gaulle took radical measures, devaluing the French franc by $14.8 \%$ and introducing orthodox economic policies.

A second important "asymmetric shock" occurred in 1968, again in France, but also in certain other countries such as Italy. The student riots and social upheavals of May 1968 led to large wage increases. Strong attacks on the French franc naturally followed. In June the French government invoked the safeguard clauses and took protectionist measures. However, De Gaulle refused to devalue the French franc ${ }^{9}$. Later, in August 1969, when Pompidou had become president, the French franc was devalued by $11.1 \%$. This episode would have a deep impact on policy-makers in the European Community as it showed the fragility of the Bretton Woods fixed exchange rate system, even within the Community.

9 Barre was one of the persons who played a key role in convincing De Gaulle that it was possible to avoid a devaluation. 
Figure 1 - Inflation and the balance of payments

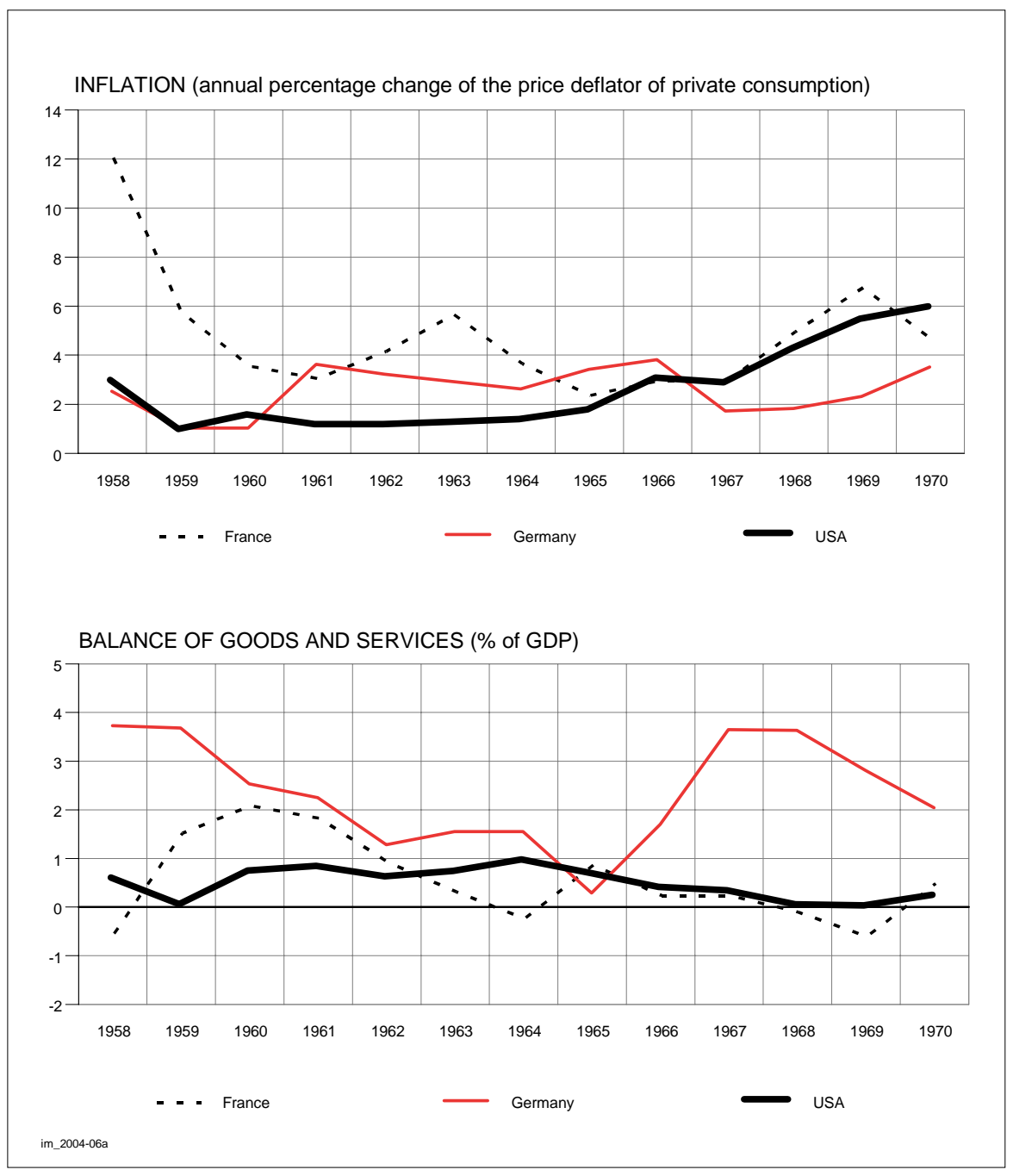

Sources: IMF (IFS) and OECD (National accounts).

As far as the external environment was concerned, for most of the 1960s the Bretton Woods system provided the European Economic Community with a favourable international monetary environment. Stable exchange rates, both between the countries of the European Community and with other countries, facilitated the integration process. However, academic discussions about the future of the international monetary system had already started, with Friedman's influential argument in favour of flexible exchange rates and Triffin's analysis of the flaws of the Bretton Woods System.

The United States took a central place in the Bretton Woods system. During most of the 1960s, especially the second half, the United States pursued expansionary monetary and fiscal policies (De Grauwe, 1989). Keynesian ideas, namely that the government had a responsibility for full employment, 
and the Vietnam war played a role in this. These expansionary polices led to an accelerating inflation and a steady deterioration of the United States balance of payments (cf. Figure 1). Consequently, the dollar was increasingly felt to be overvalued. Also, as the other countries had to maintain a fixed exchange rate with the dollar, they were forced to import inflation. It constituted an "external shock" for the European Community. In March 1961, Germany and the Netherlands had already revalued their currencies, given their sizeable external surpluses. It was an early indication of the flaws of the Bretton Woods system. It also gave an indication to the countries of the European Community that the demise of the Bretton Woods system could cause problems for the common market project. However, it was at the end of the 1960s that the real drama of the breakdown of the Bretton Woods system unfolded. Moreover, with the events of May 1968 in France, the French balance of payments also deteriorated. The main counterpart of the American and French balance of payments deficits could be found in Germany. The huge German balance of payments surplus put serious pressure on German policymakers who saw their objective of price stability threatened (Emminger, 1977). In October 1969, the German authorities decided to revalue the German mark, after letting it float for a month. The Bretton Woods system went into its final phase. In May 1971 several currencies started floating. In August 1971 Nixon decided to "suspend" the gold convertibility of the US dollar. 


\section{THE "EUROPEAN RESERVE FUND" PROJECT}

So, at the start of the EEC, the French macroeconomic and monetary situation was a matter of serious concern for the Commission. In May 1958 the French government demanded a derogation from Article 32, which concerned the use of trade quotas or equivalent measures (Minutes of the Meeting of the Commission of 3-4 June 1958, Com(58) PV 19, Archives of the European Commission). The Commission could not accept this French demand. It produced a report on the macroeconomic and monetary situation in France as well as policy recommendations (according to Article 108). Throughout 1958 the discussions between the Commission and the French authorities continued. The economic situation in France was also one of the main issues in the Monetary Committee.

These discussions also led the Commission to reflect on how it could fulfil its role in the macroeconomic and monetary area. Marjolin, in collaboration with Triffin, drew up a proposal for the creation of a European Reserve Fund. This project was one of Triffin's most important topics of analysis during his time as an advisor at the European Commission. Triffin reformulated his earlier ideas for a European Reserve Fund in an EEC framework (Maes and Buyst, 2004). It was discussed at DG II and Marjolin, in November 1958, presented a Memorandum to the Commission (see Annexes 4 to 8 in Ferrant \& Sloover, 1990) ${ }^{10}$.

Marjolin started from the observation that the EEC Treaty provided for the basic principles of the coordination of economic policies, but that the details of this coordination had not been properly worked out. So, to achieve the ambitions of the Treaty, some of its provisions needed to be supplemented and made more explicit. Marjolin further argued for a common economic policy. This would provide a way of avoiding substantial divergences in inflation and employment, which would lead to balance of payments difficulties and the application of the safeguard clauses.

To put into practice the coordination of policies, Marjolin proposed to undertake regular surveys of the economies of the Member States, in which the main economic and financial policy issues would be discussed. Moreover, he proposed that the Community institutions could also formulate policy

10 In an earlier Memorandum of 31 May 1958, Marjolin was more cautious, proposing a system of "stand-by" credit, not a European Reserve Fund (Archives Triffin). 
recommendations. The weight of these recommendations would be stronger if the Community had at its disposal resources to facilitate financial solidarity. So, Marjolin proposed to create a European Reserve Fund.

This idea, that the Community should dispose of resources to facilitate financial solidarity, would become a recurring theme in Commission proposals (see also the Barre Memorandum). A basic principle behind it was that such mechanisms, by demonstrating a collective stance, were a more efficient way of averting currency speculation than isolated national measures. Also, it made it possible to offer "carrots" to countries which had to adjust policies, increasing so the influence of the policy recommendations of the Commission. The idea is also taken up in in recent proposals to reform the system of economic governance in the EU (cf. Deroose, Hodson \& Kuhlmann, 2004).

The European Reserve Fund could be constituted by pooling $10 \%$ of the international reserves of the Member States' central banks, a proposal which was certain to arise the ire of the central bankers. The Fund would provide for different types of loans, both to assist countries with balance of payments difficulties and also to support economic growth. Marjolin also proposed that the accounts of the Fund would be expressed in a new unit of account.

The proposals then gave a key role to the Commission in the macroeconomic and monetary area. It would have a leading role in the coordination of policies and a member of the Commission would also be on the Executive Board of the European Reserve Fund, together with the central bankers and, according to the Commission proposal, the Treasury Directors.

The Commission discussed the project at its meeting of 20 November 1958. It agreed in principle with the project, but it postponed the discussion of the specific details to a future meeting (Minutes of the meeting of the Commission of 20 November, $\operatorname{COM}(58)$ PV 38, secret part, Archives European Commission). Triffin also promoted the idea actively in Paris (Triffin, 1958). However, in December 1958, De Gaulle devalued the French franc and introduced orthodox economic policies. The countries participating in the European Payments Union restored the external convertibility of their currencies in 
the framework of the Bretton Woods system. The proposal for a European Reserve Fund lost its "raison d'être".

\section{THE COMMISSION'S ACTION PROGRAMME OF OCTOBER 1962}

The first years of the EEC went well. And so, in October 1962, the Commission submitted a Memorandum with its Action Programme for the second stage of the Community (1962-1965). Walter Hallstein, the president of the Commission, drafted the political introduction, while all Commission members took part in the preparation of the programme. In the Memorandum the Commission pushed for the Rome Treaty to be interpreted in the maximum sense as implying the progressive realisation of full economic and monetary union and political union.

The introduction of the Memorandum very strongly emphasised the political character of European economic integration, which was intended to lead to the economies of the six Member States merging in a full economic union ${ }^{11}$. Economic union implied the progressive merger of national economic policies in a common short-term and long-term economic policy. This further implied that the Community would fix long-term economic objectives.

The chapter on competition policy (the area covered by von der Groeben) clearly reflected German ordo-liberal ideas. It emphasised that competition was essential for the orientation of economic activity. Moreover, it went further, linking the economic and political regime: "The economic order must also guarantee the attainment of the maximum degree of personal freedom for all those taking part in economic and social life." (Commission, 1962, p. 24).

In the chapter on economic policy (Marjolin's area), there was not only a plea for "a Community policy towards the business cycle" (p. 72), but also for a medium-term policy, "programming", at the level of the Community (p. 74). Several arguments were advanced for such "programming" at the Community level: to shed light on national and Community decisions, the effect of which is only discernible after a certain time lag; an indispensable instrument for a rational redistribution of the limited financial

11 According to von der Groeben (1995, p. 339), Marjolin was more reluctant as he feared problems, especially with the French government. 
resources of the Government; a necessary guide for national plans and programmes, as the growing openness of the economies increases the uncertainty for national actions ${ }^{12}$; a framework for Community policies for agriculture, transport and energy; to support structural adjustments, especially regional development and industrial restructuring; to support an incomes policy. The Memorandum argued that programming would not go against competition policy, but would rather reinforce competition in the Community. The Memorandum proposed that a "consolidated programme" be established for the period 1964-1968. This programme would not only define the main macroeconomic aggregates, but also the expected or desired distribution of production between the main sectors of activity. The Commission organised a conference in Rome in November 1962 to discuss these ideas (Marjolin, 1963).

In the chapter on monetary policy, another of Marjolin's areas, it was argued that monetary union could become the objective of the third stage of the common market (1966-1969). The Memorandum argued that monetary policy had a "vital importance" for the Common Market, as exchange rate fluctuations could disrupt trade flows. The Memorandum paid special attention to agriculture in this respect. Monetary union was therefore not only a way forward for the Community (Andrews, 2002). It was considered as necessary to protect the customs union and the Common Agricultural Policy - a "single market" (with common prices) for agricultural products - from exchange rate fluctuations. The German revaluation of March 1961 had in this respect an important influence on policy-makers at the Commission, as it showed the vulnerability of the international monetary system (Gleske, 2001, p. 147). For the second stage (1962-1965), the Memorandum proposed "prior consultation" for all important monetary policy decisions, such as changes in the discount rate, minimum reserve ratios, central bank loans to the State, changes in exchange rates, etc ${ }^{13}$.

It is perhaps surprising that such an ambitious programme did not include the European Reserve Fund project of just a few years earlier. However, the "logic" of the Memorandum is rather different from that of the proposal for a European Reserve Fund. The Memorandum started from the common market

\footnotetext{
12 At the French Planning Office the feeling was that the creation of the common market made planning in France more difficult. See also Benard, 1964.

13 The Commission referred to the 4th annual report of the Monetary Committee, in which it was noted that the currency revaluations of 1961 had "not been preceded by adequate coordination at Community level" (CEC, 1962, p. 37).
} 
and the common agricultural policy and explored the implications of those. It concluded that fixed exchange rates, and thus a monetary union, would be an inevitable consequence of the common market and common agricultural prices ${ }^{14}$. This rather contrasted with the proposal for a European Reserve Fund, a much more pro-active approach.

The Commission Memorandum received a rather mixed welcome. In Germany, the Frankfurter Allgemeine had an article entitled "Dangerous bridgehead for a new dirigism". Erhard criticised the Memorandum in the European Parliament. The Governors of the central banks of the Member States also discussed the Commission Memorandum. In first instance, the Governors asked for a legal analysis of whether the Council and the Commission had the right to establish regulations and directives and to take binding decisions for the central banks (La Politique Monétaire dans le cadre du Marché Commun, 4/12/62, Archives ECB). Their legal services confirmed this. In their official reaction, the Governors came out in favour of further progress in monetary cooperation between the countries of the Community and the creation of a Council of Central Bank Governors. However, they remarked that monetary coordination was also desirable in a wider framework than that of the Community, and that it could only be efficient if budgetary policy was coordinated as well. Moreover, according to the Governors, several issues, such as the reform of the international monetary system, mutual assistance and monetary union, had to be discussed first at the level of each Member State ("Note" of 10 December 1962, Archives ECB).

The discussions led to adjustments in the Commission proposals. On July 261963 the Commission submitted a Recommendation to the Council, concerning the "Medium-Term Economic Policy of the Community" (CEC, 1963b). In this Recommendation, the Commission first stressed the role of the market as the most effective instrument to ensure the best use of available resources, and the need to maintain and strengthen competition. The Recommendation further argued that the state plays a decisive role in economic life. Therefore a common medium-term economic programme was appropriate. To facilitate the formulation of this programme and to assist the coordination of medium-

14 In a note to Hallstein of 11 September 1962, Meyer, Hallstein's deputy head of cabinet, argued that "The common agricultural policy is today sufficiently firmly rooted that this understanding of its implications for monetary policy could lead to difficulties" (Archives Gleske). 
term economic policies, an advisory body, the "Medium-Term Economic Policy Committee", was proposed. It would provide a stimulus for medium-term analysis at the Commission.

On 24 June 1963, the Commission also submitted a Communication on "Monetary and Financial Cooperation in the European Economic Community" (CEC, 1963a). In that document, the Commission proposed creating two new consultative organs, the Committee of Governors of the Central Banks of the Member States of the European Economic Community and the Budgetary Policy Committee, as well as increasing the responsibilities of the Monetary Committee, especially in the area of international monetary matters. Furthermore, there was a draft decision relating to prior consultations between Member States in the event of changes in the parity of their currencies.

The new Commission proposals received a more favourable welcome and, in 1964, three new Committees were created (for Medium-Term Economic Policy, Budgetary Policy and the Committee of Governors). While the decisions of 1964 were a far cry from a monetary union, as proposed in the 1962 Commission Memorandum, they contributed to establishing the Commission as an actor in the monetary area. Firstly, they made it clear that the EEC Treaty gave a right of initiative to the Commission in the monetary area. Secondly, the Commission would be invited, as an observer, to the meetings of the Committee of Governors. This would give the Commission an entrance into the world of the central bankers. Later, this would be crucial in the development of the EMU project. Indeed, Delors, as member of the Commission who was responsible for monetary matters, participated in the meetings of the Committee of Governors. It was there that he became convinced that, for the EMU project to succeed, the central bank governors had to be on the "Delors Committee", both for their technical expertise, as well as to bind them into the project. 


\section{THE BARRE MEMORANDUM}

In the second half of the 1960 s the international monetary situation deteriorated. The Commission became worried that, if the countries of the Community did not adopt a common position, the Community risked falling apart (Minutes of the 23rd Meeting of the Committee of Governors, 12 February 1968, Archives ECB). The Commission worked out a confidential Memorandum which it presented to the Council in February 1968.

The main aim of this "Memorandum on Community Action in the Monetary Sphere" (Wissels Archives) was to establish closer monetary relations between the countries of the Community. The main proposals were: a declaration by the Member States that exchange rates would be adjusted only with prior mutual consent; the elimination of the fluctuation margins; the introduction of a system of mutual assistance; the establishment of a single European unit of account, concerted action in the international monetary institutions.

The Memorandum was very short (two pages) and the proposals were not worked out in detail. They were very much in line with the voluntarist ideas of Triffin and Boyer in DG ${ }^{15}$. They were also quite in line with French ideas, in favour of a "European monetary identity", but without new supranational institutions (de Lattre, 1999). However, the Commission proposals were criticised by Germany and the Netherlands, who argued that such a "one-sided monetary approach made no sense" (Szász, 1999, p. 11). The events of May 1968 and the ensuing crisis over the French franc, in which France invoked the safeguard clauses, further left their imprint.

In October 1968, Raymond Barre was quite sceptical about EMU and defended quite "economiststyle" positions. He declared in the European Parliament that, for EMU to succeed, a European political authority was needed (Barre, 1968, p. 17). He further argued that monetary union would be the "crowning act" of economic union. Barre went for a pragmatic and two-sided approach, arguing that the main objective had to be a better coordination of both the economic and monetary policies of the Member States. The monetary proposals were less ambitious than in the February 1968

15 In August 1967, Boyer was drawing up proposals based on the "Triffin Treasury of smart ideas", Letter by Boyer to Triffin, 2/8/67, Archives Triffin. 
Memorandum. For instance, there was no longer any mention of the establishment of a single European unit of account.

These ideas were further developed in the so-called "Barre Memorandum" of February 1969 (Commission of the EEC, 1969). The Barre Memorandum started from the observation that the Community was "an original and complex economic entity", composed of both national and Community elements. It underlined the growing economic interdependence between the Member States, implying that any incompatibility of policies and strategies could endanger the customs union. The Barre Memorandum then focused on three main lines of action:

a) convergence of medium-term economic policy. The Barre Memorandum proposed being more specific about the degree of convergence of the broad orientations of medium-term policy of the Member States and ensuring mutual compatibility. The Commission analysis thus blended the French medium-term approach with the German convergence analysis. The main objectives of these medium-term policies concerned economic growth, the movement of prices and the situation of the balance of payments.

b) the coordination of short-term economic policies. Here the emphasis was on sufficiently coherent short-term policies, so that the different economies did not develop in ways which diverged from the medium-term objectives. The Memorandum proposed the reinforcement and more effective application of the consultation procedures, before Member States decide on economic policies. The Memorandum also proposed a system of "early warning" indicators.

c) a Community mechanism for monetary cooperation, to help alleviate pressures on the foreign exchange markets. The proposed Community mechanism for monetary cooperation had to be composed of two parts: one for short-term monetary support and one for medium-term financial assistance.

Compared with the 1962 Action Programme, the Barre Memorandum was clearly much more modest and pragmatic. This is not surprising given the lack of political will, especially - but not only - in the 
France of de Gaulle. The "empty chair" crisis of 1965, when France did not take part in EEC meetings, constituted a break and induced the Commission to more cautious proposals. Moreover, the increasing divergence of national economic situations, especially with regard to inflation and the balance of payments, showed the vulnerability of the Community.

The Barre Memorandum is also characterised by a special mixture of traditional German and French ideas. This is most clear in the first part of the Memorandum, on "Convergence of medium-term economic policy ". Here the French-inspired medium-term analysis is applied to the German notion of economic convergence. By doing so, it signalled heightened concern at the Commission concerning the disparities in prices and costs in the Community countries (Note SEC(68) 3958 of 5/12/68, p. 11, Archives NBB).

The Commission's ideas for closer monetary cooperation between the Community countries initially drew very mixed reactions from the central bank governors. At their meeting of December 1968, Carli (I), while admitting the political nature of the issue, stated that he was "perplexed" at the possibility of closer monetary cooperation at Community level. He argued that the Community covered rather too small an area. Moreover, the Community constituted only a customs union and not an economic and political union (Minutes of the 27th Meeting of the Committee of Governors, 9/12/68, Archives ECB). Blessing (D) and Zylstra (N) agreed with him, while Brunet (F) and Ansiaux (B) took more subtle positions.

At their meeting in March 1969, the Governors stressed that the coordination of economic policies was the most important issue. After a thorough discussion, Ansiaux concluded that a mechanism for monetary cooperation "can be justified more on political than on economic grounds, and from that point of view we cannot be totally negative" (Minutes of the 29th Meeting of the Committee of Governors, 10/3/69, Archives ECB). After further technical monetary discussions, a Community Mechanism for Short-term Monetary Assistance was created in February 1970. 


\section{CONCLUSION}

In the mid 1950s, the six countries of the European Coal and Steel Community, followed two rather different paths to economic integration. The six opted for regional integration of the goods markets, with the creation of the EEC. However, monetary integration was approached from a more world-wide perspective, within the framework of the Bretton Woods system. These approaches would largely determine how the Commission and the central bank governors of the Community viewed monetary issues. For the Commission, monetary integration was linked with the integration of the goods markets. This contrasted with the perspective of the central bankers of the Community, for whom currency issues were, in the first instance, an issue of the international monetary system.

Macro-economic and monetary policy-making at the European Commission focussed strongly on economic imbalances in the Community, especially inflation divergences and balance of payments disequilibria, as they could threaten the functioning of the common market and the Common Agricultural Policy. From an analytical point of view, the Commission focussed on the compatibility of policies in the Member States. Gradually, a typical Commission analysis developed, based on a blending of German convergence ideas with the French medium-term approach.

The Commission was also very attentive to the system of economic governance of the Community. The Commission, on the basis of its right of initiative in the treaties, developed several proposals to strenghten monetary cooperation in the Community. In November 1958, when severe economic imbalances in France threatened the common market project, Marjolin presented a project for a European Reserve Fund at a meeting of the Commission. However, with the adoption of orthodox economic policies by De Gaulle in December 1958, it lost its "raison d'être". With the 1962 Action Programme, the Commission pushed for a maximum interpretation of the EEC Treaty, calling for economic and monetary union, a medium-term policy for the Community and political union. It encountered heavy resistance, as both France and Germany were against such a broad transfer of sovereignty. Moreover, Marjolin's idea of a medium-term plan was taboo for Erhard, the German economics minister. Also the central bankers of the Community were not enthousiastic. The ensuing decisions, in 1964, were much more modest than the initial Commission proposals. However, they 
contributed to establishing the Commission as an actor in the monetary area. Firstly, they made it clear that the EEC Treaty gave a right of initiative to the Commission in the monetary area. Secondly, the Commission was invited to the meetings of the, newly created, Committee of Governors. It would give the Commission an entrance into the world of the central bankers. The 1969 Barre Memorandum built further on these achievements. It proposed a two-pronged approach: both short-term and medium-term policy coordination to avoid economic imbalances, and a Community mechanism for monetary cooperation to alleviate pressures on the foreign exchange markets.

So, one can clearly witness an ascent of the Commission as an actor in the monetary area. The EEC Treaty accorded only a limited role to the Commission in monetary matters. During the 1960s, the Commission's influence increased. The Commission used its general right of initiative, in accordance with the Community method, to increase its influence in the monetary area. In 1964, with the creation of the Committee of Governors, the Commission acquired a place in the central bankers' club, which, later, would be of crucial importance for the EMU project. In 1970, the Commission succeeded in pushing through the creation of a Community Mechanism for Short-Term Monetary Assistance, despite the initial reluctance of the central bank governors. 


\section{REFERENCES}

Archives: Committee of Governors, ECB, Frankfurt

European Commission, Brussels

Leonhard Gleske, Bad Homberg

National Bank of Belgium, Brussels

Robert Triffin, UCL, Louvain-la-Neuve

Gerard Wissels, Overijse

Abraham J.P. \& Lemineur-Toumson C. (1981) Les Choix Monétaires Européens 1950-1980, Cahiers de la Faculté des Sciences Économiques et Sociales de Namur, April.

Andrews D. (2002) The European Commission as an Agent for Monetary Integration, mimeo.

Arena R. and Schmidt C. (1999) Keynes Before and After the General Theory: the Theoretical Contents of French Economists' Reactions, 1929-69, The Impact of Keynes on Economics in the 20th Century, L. Pasinetti \& B. Schefold (eds.), Cheltenham: Edward Elgar, pp.73-98.

Bakker A. (1996) The Liberalization of capital movements in Europe. The Monetary Committee and financial integration 1958-1994, Financial and Monetary Policy Studies 29, Kluwer Academic Publishers Dordrecht, XVIII+333 pp.

Barre R. (1968) Les Problèmes Monétaires Internationaux et la Politique Monétaire de la Communauté, Bulletin of the European Communities, Vol. 1, No 1, Nov., p. 13-19.

Barre R. (2000) Avant-Propos, in Dockès et al. (éds.), Les traditions économiques françaises 18481939, Paris: CNRS Editions, p. 17-26.

Benard J. (1964) Le marché commun européen et l'avenir de la planification française, Revue Economique, Vol. 15, No 5, p. 756-784.

Commission of the EEC, (1962) Mémorandum de la Commission sur le Programme d'Action de la Communauté pendant la 2e Etape, COM (62) 3000.

Commission of the EEC, (1963a), Monetary and Financial Co-operation in the European Economic Community, EEC Bulletin, Vol. 6, No 7, July, pp. 33-40.

Commission of the EEC, (1963b), Medium-term Economic Policy for the Community, EEC Bulletin.

Commission of the EEC (1969), Mémorandum de la Commission au Conseil sur la Coordination des Politiques Economiques au sein de la Communauté, EEC Bulletin , April.

De Grauwe P. (1989), International Money. Post-war Trends and Theories, Oxford: Clarendon Press.

de Lattre A. (1999), Servir Aux Finances, Paris: Comité pour l'Histoire Économique et Financière de la France.

Deroose S., D. Hodson \& J. Kuhlmann (2004), Economic Governance in the EU: Lessons from the First Five Years of EMU, Paper presented at the UACES conference, Birmingham, September 2004. 
Emminger O. (1958), Les aspects monétaires du Marché Commun, Bulletin d'Information et de Documentation, National Bank of Belgium, No. 2, August, p. 93-103.

Emminger O. (1977), The D-Mark in the Conflict Between Internal and External Equilibrium, 1948-75, Essays in Internal Finance, No. 122, Princeton.

Ferrant C. and Sloover J. (1990) Robert Triffin. Conseiller des Princes, Témoignage et Documents, Bruxelles: Editions Ciaco.

Gleske L. (2001) Europa auf dem Wege zur Währungsunion, Festschrift für Hans-Heinrich Otte, Düsseldorf: IDW-Verlag, pp. 145-164.

Issing O. (2000), Europe: Common Money-Political Union?, Economic Affairs, Vol. 20, No 1, March.

Jeanneney J.-M. (2004) Conclusions: Robert Marjolin, un homme d'exception, in Robert Marjolin, Institut de France, Paris, p. 111-113.

Maes I. (2004) On the Origins of the Franco-German EMU Controversies, European Journal of Law and Economics, Vol. 17, No. 1, Jan., p. 21-39.

Maes I. and Buyst E. (2004) Triffin, the European Commission and the Project of a European Reserve Fund, in M. Dumoulin (ed.), Réseaux Economiques et Construction Européenne, P.I.E. - Peter Lang, p. 431-444.

Marjolin R. (1963) Rapport Général, in Campilli P. (ed.), La Programmation Economique Européenne et la Programmation Economique Nationale dans les Pays de la C.E.E., Actes du Colloque de Rome, Vallecchi, p. 13-29.

Marjolin R. (1986) Architect of European Union. Memoirs 1911-1986, Weidenfeld and Nicolson, London.

Padoa-Schioppa T. (1998) Che Cosa ci ha insegnato l'Aventura Europea, Roma, Edizione dell' Elefante.

Pluym W. and O. Boehme (2004) De Nationale Bank van België 1959-1971, mimeo, pp. 606.

Szász A. (1999), The Road to European Monetary Union, London, MacMillan Press.

Tietmeyer H. (1999) The Social Market Economy and Monetary Stability, London: Economica.

Tinbergen J., 1954, International Economic Integration, Amsterdam: North Holland.

Triffin R. (1958) La monnaie et le Marché Commun - Politiques nationales et intégration régionale, Cahiers de I'Institut de Sciences Economiques Appliquées, No 74, December 1958, p. 1-17.

Van Tichelen J. (1981) Souvenirs de la Négociation du Traité de Rome, Studia Diplomatica, vol. 34, no $1-4$.

von der Groeben H. (1979) The Role of European Integration in the West German Economic Order, Zeitschrift für die gesamte Staatswissenschaft, Vol. 135, No 5, p. 493-509.

von der Groeben H. (1995) Deutschland und Europa in Einem Unruhigen Jahrhundert, Baden-Baden: Nomos. 


\section{Annex 1: List of persons interviewed}

- Jean-Paul Abraham (B), European Coal and Steel Community (6-6-2000)

- Michel Albert (F), Director DG II (9-11-2000)

- Raymond Barre (F), Vice-President of the Commission, Economic and Financial Affairs (6-12-2001)

- Georges Berthoin (F), Chef de cabinet of J. Monnet (30-10-2002)

- Daniel Cardon (B), Chef de cabinet of A. Coppé (15-5-2001)

- Roland de Kergorlay (F), Secretary of the Monetary Committee (27-11-2001)

- Jean Flory (F), Chef de cabinet of R. Marjolin (5-12-2001)

- Franz Froschmaier (D), Advisor to H. Von der Groeben and W. Haferkamp (16-7-1997, 6-5-2004)

- Leonhard Gleske (D), Director DG II (18-12-2001)

- Andreas Kees (D), DG II (28-11-2001)

- Manfred Lahnstein (D), Chef de cabinet of W. Haferkamp (11-6-2002)

- André Louw (B), DG II (22-8-1997, 24-7-2001)

- Pierre Millet (F), Director DG II (20-2-2003)

- Bernhard Molitor (D), Director DG II (8-3-2001)

- Jean-Claude Morel (F), Head of Unit DG II (17-8-2000, 5-11-2000)

- François-Xavier Ortoli (F), Director-General DG III (4-12-2001)

- Jean-Claude Paye (F), Chef de cabinet of R. Barre (23-3-2001, 8-1-2003)

- Giovanni Ravasio (I), DG II (10-4-2002)

- Ludwig Schubert (D), DG II (25-8-2000, 25-4-2001)

- Umberto Stefani (I), Assistant to the Director-General, DG II (31-10-2001)

- Roland Tavitian (F), Director DG II (14-11-2003)

- Robert Toulemon (F), Chef de cabinet of R. Marjolin (23-1-2002)

- Paul van den Bempt (B), DG II (5-6-1997)

- Hans von der Groeben (D), Member of the Commission, Competition Policy (23-7-2001)

- Manfred Wegner (D), DG II (2-9-1997)

- Gerard Wissels (N), Advisor to D. Spierenburg, Director DG II (10-1-2003, 18-3-2003)

Persons at the Commission during the period under consideration. Function relating to this paper and date of the interview. 